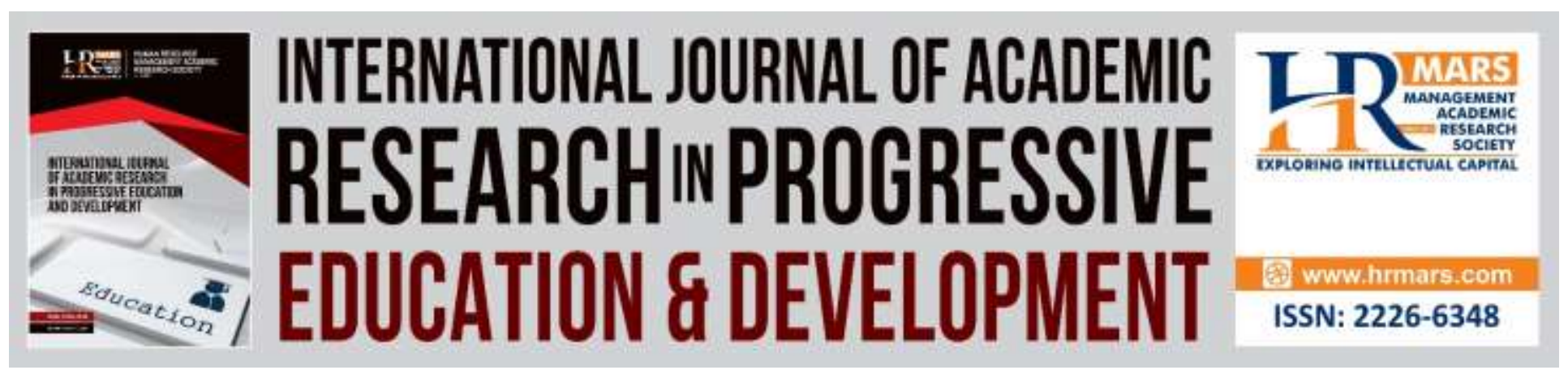

\title{
Education from the Eyes of our Children: Qualitative Exploration on Implementation of Quranic Component in the Ulul Albab Curriculum
}

Naremah Hameran, Mohd Mokhtar Muhamad, Umi Kaltom Abdul Manaf, Ady Hameme Nor Azman

To Link this Article: http://dx.doi.org/10.6007/IJARPED/v8-i4/6695

DOI:10.6007/IJARPED/v8-i4/6695

Received: 14 October 2019, Revised: 30 October 2019, Accepted: 01 November 2019

Published Online: 25 November 2019

In-Text Citation: (Hameran, Muhamad, Manaf, \& Azman, 2019)

To Cite this Article: Hameran, N., Muhamad, M. M., Manaf, U. K. A., \& Azman, A. H. N. (2019). Education from The Eyes of Our Children: Qualitative Exploration on Implementation of Quranic Component in the Ulul Albab Curriculum. International Journal of Academic Research in Progressive Education and Development, 8(4), 713723.

Copyright: (c) 2019 The Author(s)

Published by Human Resource Management Academic Research Society (www.hrmars.com)

This article is published under the Creative Commons Attribution (CC BY 4.0) license. Anyone may reproduce, distribute, translate and create derivative works of this article (for both commercial and non-commercial purposes), subject to full attribution to the original publication and authors. The full terms of this license may be seen at: $\underline{\text { http://creativecommons.org/licences/by/4.0/legalcode }}$

Vol. 8(4) 2019, Pg. 713 - 723

http://hrmars.com/index.php/pages/detail/IJARPED

JOURNAL HOMEPAGE

Full Terms \& Conditions of access and use can be found at http://hrmars.com/index.php/pages/detail/publication-ethics 


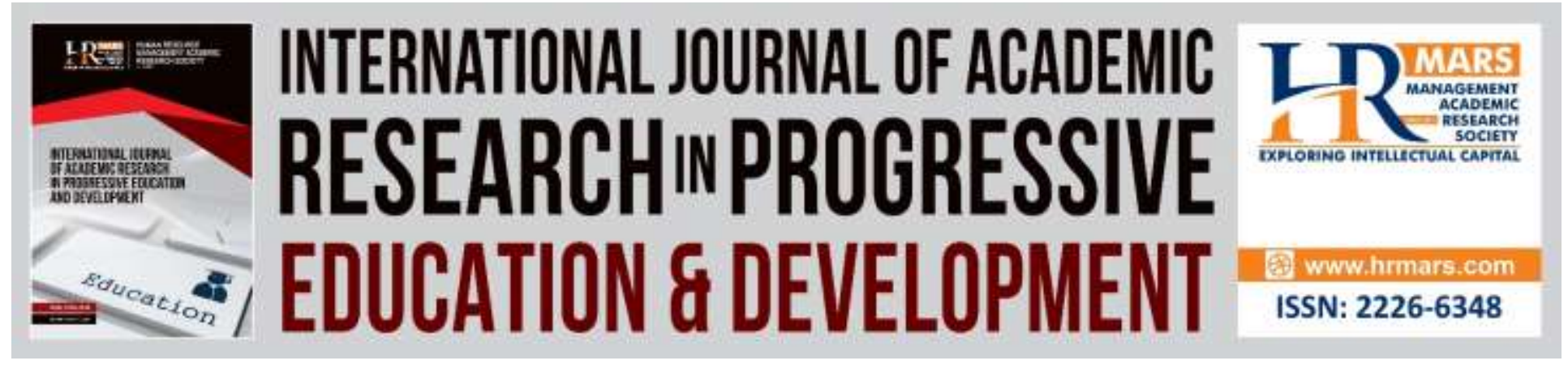

\title{
Education from The Eyes of Our Children: Qualitative Exploration on Implementation of Quranic Component in the Ulul Albab Curriculum
}

\author{
Naremah Hameran ${ }^{1}$, Mohd Mokhtar Muhamad ${ }^{2}$, Umi Kaltom \\ Abdul Manaf ${ }^{2}$, Ady Hameme Nor Azman ${ }^{3}$ \\ ${ }^{1}$ Faculty of Educational Studies, Universiti Putra Malaysia (UPM), 43400, Serdang, Selangor, \\ Malaysia, ${ }^{2}$ Department of Foundation of Education, Faculty of Educational Studies, Universiti \\ Putra Malaysia (UPM), 43400, Serdang, Selangor, Malaysia, ${ }^{3}$ Inspiora Resources, Malaysia
}

\begin{abstract}
Beauty is in the eyes of the beholder, they said. But what is beauty? Some might say it is the aesthetic part of anything, while others might say it is the determinant of wages discriminant among corporate worker (Sierminska \& Liu, 2015). And who to say some are wrong and some are right, for we are entitled to form our opinion individually. It is the gift of our faculties that provide us our unique understanding on how we process our cognitive contact with the world around us (Efron, 1969). By understanding that individual perceive things differently, this research embarks on exploring how Form Four students in an esteemed Ulul Albab school perceive their education, particularly on quranic aspect of the Ulul Albab curriculum. This research is a case study which involves a total of six informants selected by typical purposive sampling. A semi-structured focus group interview was conducted in this study. The instrument was developed by researchers and its content has been validated by panel of experts. The interviews were analyzed mainly using constant comparative method utilizing Atlas ti.8 software. The analyzed data led to the conclusion of three sub-themes explaining the crux theme; Guidance for the afterlife/hereafter.
\end{abstract} Keywords: Ulul Albab, Quranic, Perception, Students.

\section{Introduction}

Malaysian witnessed a great shift in education paradigm after the $14^{\text {th }}$ general election when the spotlight in education has been shifted towards Technical and Vocational Education and Training (TVET) in Malaysia. According to Chonghui (2019), current Minister of Education Dr. Maszlee Malik, emphasis the advancement of TVET starting this year to promote TVET as a tool to churn out correct personnel to meet the industrial's demand for competent workers. This is all due to the surge of Industrial Revolution which benefit us through interesting additional elements in education such as the emphasis on technical and vocational education (Phoenix, 2001), skillbased education (Ng-He, 2015), and integrating Information and Communication Technology 
(ICT) in education. Human progress, however is not measured by the progression of the world we are living in, nor by the industry that monopolized the economy of the world. It is however, measured by the value that were place on the life of an individual (Wilson, 2017).

As a Muslim, this includes the elements of the theological meaning of Islam, the transcendence and indivisibility of Allah, the role of Muhammad (PBUH) and his deeds and sayings (hadith), the importance of the Quran to Islam, Sharia (law), the Five Pillars of Islam, the Six Pillars of Faith, the contributions of Muslims to world civilization, and the reasons for the rapid expansion of Islam and the divisions within Islam (Nord \& Haynes, 1998).

The emphasis of religion in education system is paramount and to put it in Nord's (2011) words, "an educational system that ignores the great existential questions; political, moral, spiritual, religious, is not worthy of respect, indeed, it shouldn't count as educational at all." According to Ahmad Fauzi (2018), one of the significant scholars who greatly contributed and influenced the discourse of Islamic education in Malaysia is Syed Naqiub Al-Attas. As a philosopher, Syed Naquib Al-Attas has innovatively re-conceptualized the notion of "education" as $t a^{\prime} d \bar{i} b$; "the instilling and inculcation of $a d a b$ in man". Adab here provide meaning as embodying the processes of disciplining the mind and soul, acquiring good qualities for the mind and soul, performing correct as against fallacious action, and thus preserving mankind from great mortification (Al-Attas, 1980).

Al-Attas' preference for $t a^{\prime} d \bar{i} b$ in elucidating an understanding of education, as compared with other concepts which have also gained wide currency within Muslim educational circles such as tarbiyah and ta'lim, and is underscored by $t a^{\prime} d \bar{i} b^{\prime}$ 's human-specific quality, recognizing the nature of human's spiritual constitution as made up of soul (nafs) and intellect ('aql), which are responsible for the fulfilment or neglect of one's actions as part of one's individual covenant with God (Al-Attas, 1980).

$T a^{\prime}$ lim and tarbiyah, by contrast, have more generic attributes, connoting respectively "the teaching and learning process" and the multiple actions of "bringing out," "developing," "nurturing," "fostering," "nourishing," "rearing," and "cherishing" as applied to objects under one's possession (Halstead, 2004). As such, the corollary of $t a^{\prime} d i \bar{b}$ is not necessarily quantifiable, as more than usually is the case with the end product of ta'lim and tarbiyah.

\section{Brief History of the Implementation of Ulul Albab Curriculum}

Inspired by Al-Attas' moralistic outlook, Malaysian scholars have broadly arrived at an understanding of Islamic education as an integrated process of imparting Islamic knowledge such that its students are equipped spiritually, intellectually, and materially in order for them to carry out their God-ordained roles as His servants and vicegerents on earth (Kamal Hassan,1986; Zawawi Ahmad, 1994).

Correspondingly, as part of Malaysia's education system, in 1999, the Ulul Albab program was first implemented in Sekolah Menengah IMTIAZ Yayasan Terengganu as pioneered school. Mapped by undergoing 20 years of curriculum development, the Ulul Albab program implemented in Sekolah Menengah IMTIAZ Yayasan Terengganu is an unique dual-streamed curriculum which integrating mainstream Kurikulum Bersepadu Sekolah Menengah (KBSM) and Program Hafazan Al-Quran. According to Mohd Arshad (2015), the Ulul Albab program comprises three main components, namely; quranic, encyclopedic and ijtihadik. 
Vol. 8, No. 4, 2019, E-ISSN: 2226-6348 @ 2019 HRMARS

According to the manual laid down by Yayasan Terengganu in Sistem Pelaksanaan Kurikulum, Ko-Kurikulum dan Hafazan Al-Quran Sekolah Menengah IMTIAZ, the implementation of quranic component in Sekolah Menengah IMTIAZ Yayasan Terengganu consists of Tasmi', AlQuran and Dinniyah elements. Dinniyah elements consist five subjects; Tauhid, Feqah, Tafsir, Hadith and Sirah. The implementation of the three elements in quranic component takes out $40.70 \%$ from the allocated 54 learning hours. As implementation of quranic components required almost constant supervision from teachers, students spend great deal of their time in the company of their teachers.

\section{Teachers as Agents of Instructional Improvement}

Edith Mary Tolkien said mere word is meaningless. It is just beautiful sound, she said. It is the marriage between the word and its meaning and significance that brings about its utter essence in interpreting the meaning of any words. This case is particularly applicable in interpreting the design and spread of any curriculum. Ball and Cohen (1996) ruled out three main reasons to justify uneven role of curriculum materials in United States; failure to take account of the teacher, fundamental ways of shaping the curriculum and rejection of text-books by reformoriented teachers. According to Ball and Cohen (1996), this situation leads to great disparity between the intention of curriculum developers for students and the implementation of the curriculum in class. Positive influence is very much welcome and needed. However, any negative influences will hinder the achievement of curriculum's aims set by the curriculum designers. As teachers can necessarily select from and adapt materials to suit the need of their students, researcher must be innovative in evaluating the implementation of the curriculum, particularly in one such as the Ulul Albab curriculum.

According to Umi Kalthom and Fadzilah (2017), due to the increments in $21^{\text {st }}$ century curriculum designs that combining not only the intellectual domain but also affective and social domains, the urgency of having humanistic and holistic curriculum evaluation is essential. Such statement is notably relatable in the Ulul Albab curriculum. And what better ways to evaluate a curriculum beside from the eyes of the veteran of the curriculum itself.

According to Howard et al. (2004), curriculum evaluation particularly in the studies of students performance often rely on student perception in determining the quality and quantity of their learning experiences. The perception of the students who experience the implementation of quranic component in the Ulul Albab curriculum is valuable as direct first-hand feedback on the overall implementation of the quranic component. As explained by Efron (1969), perception id defined as "the direct, immediate awareness of discriminated existents which results from patterns of energy absorption by groups of receptors". Putting all fancy words aside, the quintessential of Efron (1969) definition of perception is one awareness on stimulants revolving around themselves which affected by external factors. In the case of our study, it is the awareness of students on the quranic components implemented through the Ulul Albab curriculum.

\section{Purpose of the Study and Research Question}

The overall purpose of this study was to explore the experience of the implementation of quranic component in Ulul Albab curriculum among Form Four students in an esteemed Ulul Albab school. More specifically, the research questions that guided this study are: 
Vol. 8, No. 4, 2019, E-ISSN: 2226-6348 @ 2019 HRMARS

1. How quranic component experienced by students?

2. How does school shape these experiences?

3. How is quranic component perceive by Ulul Albab students and what are the barriers they encounter with respect to the implementation of quranic component?

\section{Research Method}

According to Merriam (2009), patrons of qualitative study such as Pattons, Cresswell, Denzin and Lincoln have their own approaches and classification when it comes to organize the diverse form of qualitative research. These trailblazers, however agree upon one brief overview; there is no correct number on listing the approaches to qualitative research (Creswell, 2007). For this hold true to the quintessential of a qualitative study which is, researcher is the primary instrument of qualitative research (Merriam, 2009). Among the various approaches of qualitative research, this study adapted qualitative case study as research design. Merriam (2009) defines research design as a map from Point $A$ to Point $B$ where Point $A$ is the research question and Point $B$ is the answer to the question. Without research design as a plan on how to conduct the study, it may go haywire. As Bilbo Baggin said:

It's a dangerous business, Frodo, going out your door. You step onto the road, and if you don't keep your feet, there's no knowing where you might be swept off to."

\section{Sampling}

After approvals were obtained from Malaysia Ministry of Education, Jabatan Pendidikan Negeri Terengganu and the school itself, six participants were identified from the Ulul Albab school in Besut, Terengganu by utilizing typical purposive sampling. The participants were briefed by our researchers shortly before the interview began on the purposes of our study and ethical discretion uphold in this study. During the briefing, all questions from the participants were addressed. Informed consent was obtained verbally and in writing at the time of the interview. All females and male participants had self-identified themselves as Ulul Albab students, were able to communicate effectively and aged 16 years old. The rationale for the age limit is that 16 years old student is a Form Four student who did not have to sit for major examination such as Sijil Penilaian Menengah (SPM) examination and was already well versed and adapted to Ulul Albab curriculum after three years previously as Ulul Albab student. All of six participants are Muslim. The total sample consisted of 3 male and 3 female participants. One group interview was conducted involving all of the participants. All participants were classmates and considered each other as friends. The determinant of sample size was decided during the course of the research when all research questions were answered extensively by the participant, as suggested by Merriam (2009); "What is needed is an adequate number of participants to answer the questions posed at the beginning of the study".

\section{Data Collection Procedure}

The group interview followed a semi-structured interview protocol which consisted of 12 open-ended questions. Interview protocol utilized in this study was constructed by our research team through in-depth discussions, mock interviews and was validated by a panel of experts at 
Faculty of Education, Universiti Putra Malaysia. Each open-ended question has at least two probing question to venture in-depth information and clarification from the participants. As suggested by Patton (2002), researchers also combined field notes obtained after the group interview as a mean to assist in data analysis after the interview.

\section{Data Analysis}

The group interview lasted for 96 minutes approximately and was audio-recorded as well as video-recorded. The verbatim obtained from the interview was transcribed as soon as possible following the interview by the interviewer herself. Once the transcribed verbatim was finished, it was reviewed by second interviewer to ensure its accuracy. It was then analyzed using constant comparative method by utilizing the Atlas.ti version 8 software which mainly involved repetitive readings of the transcript to curdle out the point of arguments during the interview. As suggested by Bringer, Johnston, and Brackenridge (2006); Haji-Othman, Fisol, Yusuff (2018), a list of codes was identified in the initial process of open coding from the repetitive readings of the transcript. The list then diverged into categories in axial coding process which eventually categorized into themes to provide answers in regards to research questions in this study.

\section{Findings}

Truth be told, participants of this study are definitely in a different league from our average students. The interview was conducted actively as the participants were excited to share their stories and did so in an insightful way. From their narratives, three sub-themes emerged leading to the crux theme; Guidance for the afterlife/hereafter. The three sub-themes are; (I) foundation for future endeavor, (II) thirst for overlapping knowledge in nourishing environment, and (III) the ultimate guidebook in urgency to finish it all. These findings will be addressed in relation to the participant's stories.

\section{"This is all for our future": Foundation for Future Endeavor}

Several participants expressed the belief that it was dully due to adaptation after nearly four years of living neck-to-neck time table is the reason they are feeling okay with time constrain and tiring schedule of an Ulul Albab student. It is a unanimous decision that the daily schedule of anyone in school team in any contest or participation is more gruesome than other. As one participant explained:

I 3: "Penat, tapi dah biasa. Kalau nak compare, yang masuk pertandingan lagi penat, ada latihan petang".

14: So, UA ini, dia untuk dua-dua; dunia dan akhirat. Siapa yang nak dunia, dia perlukan duit, so kena ada ilmu. Nak akhirat sahaja, dia perlukan ilmu, ilmu solat, ilmu puasa. Dan kalau nak dua-dua, UA ini ada semua. Semua datang dari Al-Quran.

During school, the participants immersed themselves in quranic classes which enlisted in Syahadah Al-Ulya program. This is an extensive program offered exclusively for students who already achieve the requirement of memorizing 30 juzu' of Al-Quran. In this program, with 
Vol. 8, No. 4, 2019, E-ISSN: 2226-6348 @ 2019 HRMARS

guidance from their teacher, they discussed not only the direct translation of the Quran, but also the interpretation of Al-Quran from Tafsir Al-Jalalain. From the lenses of outsider as researchers, it was so tiring and exhausting. Yet, the participants bolted a statement that emphasis their belief that the fruit of our hard work is indeed the sweetest:

\section{2: Penat, tetapi kejayaan tak datang dengan mudah.}

The justification of their compact schedule and intense curriculum was fully grasped by the participants. The notion that one must not forgo the balance of worldly; duniawi and ukhrawi knowledge is fully comprehended by participant.

I 4: Nabi kata, siapa yang nak dunia, dia memerlukan ilmu, siapa yang nak akhirat, dia perlukan ilmu dan siapa yang nak dua-dua, dia perlukan ilmu.

They argued that quranic component is a compulsive aspect of knowledge that they must strive to soak in for the hereafter. As one of them explained:

The participants also perceived their experiences as Ulul Albab students as foundation for future endeavor which will allow them to excel in their professional field later on in their life as practicing professional Muslim. It is believed that the knowledge they learned in Ulul Albab curriculum, particularly from quranic component will serve them well in functioning as, to put in their words; Ulama Profesional

1 3: Lepas itu untuk menjadi rujukan pun senang, maksudnya bukanlah sedikit sahaja orang yang ada asas-asas agama dan semua itu. Maksudnya boleh dijadikan rujukan dalam kehidupan seharian kita lah.

It was mutual agreement that they believed the knowledge that they learned in extensive programme such as Syahadah Al-Ulya barely scraped the surface of quranic element.

I 2: Tafsir ini bukan semua. Dia ada certain sahaja, mengikut muqarrar. Tak terlalu mendalam. Pengenalan kepada tafsir. Sebelum masuk dengan lebih mendalam, dekat sekolah menengah ini, kita belajar sikit dahulu (tafsir). "Oh, kitab ini untuk ini, kitab ini untuk ini". Nanti lepas habis sekolah, boleh mendalami lagi.

In summary, it is believed that quranic experience in Ulul Albab curriculum is a platform for participants to build up their knowledge after finishing their secondary school education.

\footnotetext{
"I want more, I need more": Thirst for Overlapping Knowledge in Nourishing Environment

On several parts of the interview, participants discussed their desire to learn in great details about knowledge intertwining their quranic knowledge and lesson learnt in class. They are eager to know more about finding derived from Al-Quran from their teachers relating to the
} 
subjects. As explained by one of the participants, teachers are unable to corelate the content of their subject and quranic element in teaching.

12: Nak tahu, tapi macam kita tahu, cikgu-cikgu bukan basic-nya UA atau al-Quran. Jadi cikgu ajar berdasarkan bidang cikgu sahaja.

Participants also expressed that facts uttered by teachers which intertwining these two elements during class was key element to enhance the grasp of knowledge in classes. They were mesmerized by the fact told by one of their teachers who explained the relationship of His punishment toward sinner who commit adultery; 100 canning and the release of antibody after canning to combat the virus from destroying the body.

I 2: Sebagai contoh, dulu saya ada guru bahasa arab. Tapi dia tak ajar bahasa arab sahaja, dia kaitkan dengan ilmu yang luas. Dia mampu kaitkan bahasa arab dengan al-Quran. Bila dia kaitkan dengan al-Quran, dia kaitkan dengan Sains.

Yet, according to the participants, their needs of intertwining their quranic knowledge and lesson learnt in class was not meet. However, participants do believe that their teachers tried the hardest that they can in providing means to their need. One of the participants explained:

1 6: Macam cikgu Fizik ini, dia tahu yang dia ajar anak murid UA. Jadi dia cuba yang terbaik untuk dia, dia selalu takut yang kami tak faham, jadi dia try hard untuk fahamkan kita. Siap pasang video semua.

Feeling loved and appreciated, one of the participants expressed her gratefulness toward her teacher for their effort in teaching them the best they that they could:

I 5: Guru-guru KBT, di bawah UA ini di dalam usaha untuk mengukuhkan hafazan para pelajar. Guru-guru tasmi especially. Contoh untuk pelajar-pelajar KBT, dia ada program hifz ul-Quran, dia tebuk. Tebuk quran. Guru-guru sangat berusaha untuk mengukuhkan hafazan para pelajar untuk betul-betul menjaga Al-Quran.

In summary, participants explained that they want to learn more in details regarding knowledge relatable to their quranic knowledge from their teachers. Their academic teachers, however does not possess the knowledge in quranic element to relate the content of their subject in teaching the students. Although it is not fulfilled, participants strongly believed that their teachers are doing the best that they can in helping them with the knowledge that they possess.

\section{"It's okay, this shall be over": Ultimate Guidebook in Urgency to Finish It All}

During interview, participants were asked on the additional elements that should be installed in the future revised Ulul Albab curriculum. They suggest for the installation of soft skill elements alongside the emphasis of the art of communication in the Ulul Albab curriculum: 
INTERNATIONAL JOURNAL OF ACADEMIC RESEARCH IN PROGRESSIVE EDUCATION AND DEVELOPMENT

Vol. 8, No. 4, 2019, E-ISSN: 2226-6348 @ 2019 HRMARS

According to the participant, in order to fully achieve the aim of Ulul Albab curriculum, the additional of these two elements is a must. The participants were adamant that in the Ulul Albab curriculum, it is essential that these elements were derived from the Al-Quran itself.

\section{2: Al-Quran dan kitab-kitab lama lah.}

I 2: Untuk Syahadah Al-Ulya, kita ada satu kitab, iaitu Hidayah, yang fokus pada adab-adab sahaja.

I 1: Saya rasa kalau satu lagi, adalah dari segi bidang softskill. Kita ini kena ada seni dalam kita berkata-kata.

Holding true to the belief that quranic components in Ulul Albab curriculum is the ultimate guidance, participants believed that the knowledge will guide them even in trivial aspects of life. They also believe that the guidance from the quranic elements will help them in obtaining indepth knowledge in various discipline. Yet, any advancement in knowledge obtained comes with the price of living a fast pace schedule as a Ulul Albab student. Thus, the participants expressed the feeling of urgency to soak in the available knowledge in the few years that they have as Ulul Albab student at their school. However, as explained by one of the participants, the fast learning environment in the Ulul Albab curriculum is made less stressful by the quranic components itself. they find solace and treat the practice of quranic components as stress-reliver.

1 2: Dia tak stress pun dekat sini sebab ada Al-Quran. Kadang malam rasa penat. Tapi malam ada kelas quran. Tapi bila kita mengaji itu, rasa tenang.

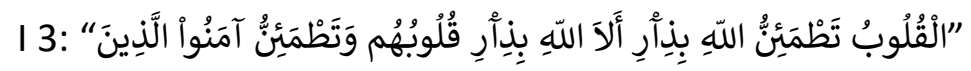

Dengan mengingati Allah, hati menjadi tenang.

In summary, the participants perceived quranic components as guidance to prepare them for the life after school. Thus, they understand the value of knowledge that was bestowed upon them.

\section{Conclusion}

All of the participants contributed stories that included idea and issues that were current in their lives. As students, they discussed current environment according to their perception as active participants and stake holder in the Ulul Albab curriculum. Ultimately, the participants perceived the implementation of quranic components in their school as preparation for them to progress and venture out as a successful individual and ultimately as live-saving to bring with them for the hereafter.

In preparing them to do so, the participants believed that the current fast paced learning environment cannot be dodge and must be faced forward. As they fully understand the aims that guided the implementation of Ulul Albab curriculum in their school, they are willing to serve their 
part as student. However, the demand and supply line of knowledge is insufficient to nourish the students up to their full potential. According to the participants, the integrating elements which combining the elements in quranic components and encyclopedic elements in class is not sufficient. Yet, the participants also understand that their teachers do try to patch up the lack of integrated elements the best that they can. Throughout the interview, all participants speak dearly of their teachers. Through these findings, numbers of stakeholders may benefit from the data presented especially in understanding the current implementation of quranic components in Ulul Albab curriculum from the perspective of the students. The curriculum developers will be able to sketch additional elements in revising a better Ulul Albab curriculum.

\section{Acknowledgement}

This research was made possible due to research grant in the scheme of Geran Putra by Research Management Centre, Universiti Putra Malaysia.

\section{Corresponding Author}

Mohd Mokhtar Muhamad (PhD), Department of Foundation of Education, Faculty of Education, Universiti Putra Malaysia, 43400, Serdang, Selangor, Malaysia

Email: mk_mokhtar@upm.edu.my

\section{References}

Fauzi, A. H. (2018). Handbook of Islamic Education. 7, 1-17. https://doi.org/10.1007/978-3-31953620-0.

Al-Attas, S. M. N. (1980). The Concept of Islamic Education. X. https://doi.org/10.1007/s13398014-0173-7.2

Ball, D. L., \& Cohen, D. K. (1996). Reform by the book: What is-or might be-the role of curriculum materials in teacher learning and instructional reform? Educational Researcher, 25(9), 614. https://doi.org/10.3102/0013189X025009006

Bringer, J. D., Johnston, L. H., \& Brackenridge, C. H. (2006). Using Computer-Assisted Qualitative Data Analysis Software to Develop a Grounded Theory Project. Field Methods. https://doi.org/10.1177/1525822X06287602

Creswell, J. W. (2007). Qualitative Inquiry \& Research Design. In Sage Publications, Inc. https://doi.org/10.1111/1467-9299.00177

Efron, R. (1969). What is Perception? In R. S. Cohen \& M. W. Wartofsky (Eds.), Proceedings of the Boston Colloquium for the Philosophy of Science 1966/1968 (pp. 137-173). https://doi.org/10.1007/978-94-010-3378-7_4

Halstead, J. M. (2004). An Islamic concept of education. Comparative Education, 40(4), 517-529. https://doi.org/10.1080/0305006042000284510

Howard, T. C., Efron, R., Kardash, C. A. M., Chung, J. C. C., Chow, S. M. K., Hill, Y., ... Pollard, D. S. (2004). Students Perception of Required Volunteerism. Malay, 6(2), 75. https://doi.org/10.1108/09684880310462047

Merriam, S. (2009). Qualitative Research: A Guide To Dedign and Implementation. In John Wiley \& Sons. https://doi.org/10.1017/CBO9781107415324.004

Arshad, M. A. (2015). Ulasan Sistematik: Program Ulul Albab dalam Sistem Pendidikan Di 
INTERNATIONAL JOURNAL OF ACADEMIC RESEARCH IN PROGRESSIVE EDUCATION AND DEVELOPMENT

Vol. 8, No. 4, 2019, E-ISSN: 2226-6348 @ 2019 HRMARS

Malaysia. Jurnal Kurikulum \& Pengajaran Asia Pasifik, 22-35.

$\mathrm{Ng}-\mathrm{He}$, C. (2015). Common Core: Skill-Based Learning. Journal of Museum Education, 40(3), 219225. https://doi.org/10.1179/1059865015Z.00000000098

Nord, W. (2011). Does God Make a Difference?: Taking Religion Seriously in Our Schools and Universities. In Does God Make a Difference?: Taking Religion Seriously in Our Schools and Universities. https://doi.org/10.1093/acprof:oso/9780199766888.001.0001

Nord, W. A., \& Haynes, C. C. (1998). Taking Religion Seriously Across the Curriculum Education as a Moral Enterprise. Premium Member Book.

Patton, M. Q. (2002). Qualitative research and evaluation methods. Thousand Oaks. Cal.: Sage Publications.

Phoenix, D. A. (2001). Increasing the emphasis of vocational qualifications. Journal of Biological Education (Society of Biology), p. 163. Retrieved from http://simsrad.net.ocs.mq.edu.au/login?url=https://search.ebscohost.com/login.aspx?di rect $=$ true $\& d b=a p h \& A N=5257628 \&$ site $=$ ehost-live

Sierminska, E. M., \& Liu, X. M. (2015). Beauty and the Labor Market. In International Encyclopedia of the Social \& Behavioral Sciences: Second Edition. https://doi.org/10.1016/B978-0-08097086-8.94015-7

Kalthom, U. A. M., \& Fadzilah, A. R. (2017). Evaluating the Humanistic Curriculum Implementation of MRSM Ulul Albab Program. International Journal of Academic Research in Business and Social Sciences, 7, 237-244. https://doi.org/10.6007/IJARBSS/v7-i14/3664

Haji-Othman, Y., Fisol, W. N. M., Yusuff, M. S. S. (2018). The Moderating Effect of Islamic Religiosity on Compliance Behavior of Income Zakat in Kedah, Malaysia, International Journal of Academic Research in Accounting, Finance and Management Sciences 8 (2): 281-286. 